\title{
Hepatitis B Virus Persistence after Recovery from Acute Viral Hepatitis
}

\author{
Thomas I. Michalak, Claudio Pasquinelli, Stephane Guilhot, and Francis V. Chisari \\ Department of Molecular and Experimental Medicine, The Scripps Research Institute, La Jolla, California 92037
}

\begin{abstract}
Contrary to current opinion, the disappearance of hepatitis B surface antigen (HBsAg) from the serum, the development of anti-HBs antibodies, and normalization of liver function may not reflect complete virological recovery from acute hepatitis $B$ virus (HBV) infection. By using the polymerase chain reaction (PCR), in the current study we demonstrate long-term persistence of HBV DNA in the serum and peripheral blood mononuclear cells (PBMC) of four patients for up to 70 mo after complete clinical, biochemical, and serological recovery from acute viral hepatitis. Serum HBV DNA reactivity co-sedimented with HBsAg in sucrose gradients, and it displayed the size and density characteristics of naked core particles and intact $\mathrm{HBV}$ virions, presumably contained within circulating immune complexes in these anti-HBs antibody-positive sera. HBV DNA was also present in PBMC in late convalescent samples from all four patients, and HBV RNA was detected in late convalescent phase PBMC in two of these patients. These results suggest that HBV DNA, and possibly $\mathrm{HBV}$ virions, can be present in the serum, and that the viral genome can persist in a transcriptionally active form in PBMC for $>5 \mathrm{yr}$ after complete clinical and serological recovery from acute viral hepatitis. ( $J$. Clin. Invest. 1994. 93:230-239.) Key words: hepatitis B • hepatitis $B$ virus $\bullet$ immunity $\bullet$ liver diseases $\bullet$ polymerase chain reaction • viral DNA
\end{abstract}

\section{Introduction}

Seroconversion to hepatitis B surface antigen ( $\mathrm{HBsAg})^{1}$ negativity with the appearance of antibodies to $\mathrm{HBsAg}$ (anti-HBs) and normalization of liver function have been generally accepted as evidence of viral clearance during acute hepatitis B (1). However, since hepatitis B virus (HBV) DNA sequences may persist in the liver and serum in patients with chronic hepatitis long after disappearance of $\mathrm{HBsAg}$ and appearance of anti-HBs (2-5) it is possible that viral DNA may not be com-

This is Publication 7856-MEM from the Scripps Research Institute.

Dr. Michalak's permanent address is Liver Research Laboratory, Division of Basic Medical Sciences, Faculty of Medicine Memorial University of Newfoundland, St. John's, NF, Canada A1B 3V6.

Address correspondence to Dr. Francis V. Chisari, Department of Molecular and Experimental Medicine, BCR-10, The Scripps Research Institute, 10666 North Torrey Pines Road, La Jolla, CA 92037.

Received for publication 7 July 1993 and in revised form 19 August 1993.

1. Abbreviations used in this paper: anti-HBs, antibodies to $\mathrm{HBsAg}$; CAHB, chronic active hepatitis B; EB, ethidium bromide; $\mathrm{HBsAg}$, hepatitis B surface antigen; HBV, hepatitis B virus; SL-AH, self-limited acute hepatitis.

J. Clin. Invest.

(C) The American Society for Clinical Investigation, Inc. $0021-9738 / 94 / 01 / 0230 / 10 \$ 2.00$

Volume 93, January 1994, 230-239 pletely eradicated at the time of clinical, biochemical, and serological recovery from acute $\mathrm{HBV}$ infection. This is supported by the demonstration of woodchuck hepatitis virus DNA in livers and peripheral blood lymphocytes of apparently healthy woodchucks after serological and biochemical recovery from acute hepatitis (6). In addition, there is growing evidence that the HBV genome persists in serum and liver despite the clearance of serum $\mathrm{HBsAg}$ and anti-HBs seroconversion during antiviral therapy for chronic hepatitis $B(5,7-10)$. In some of these patients, HBV DNA sequences were detected in PBMC several years after the disappearance of $\mathrm{HBsAg}$ from serum (11).

To determine whether HBV might persist in the circulation after complete serologic and clinical recovery from acute hepatitis B, we examined serum and PBMC of healthy individuals with a history of self-limited acute hepatitis B (SL-AH) infection for HBV DNA using the PCR. We have found HBV DNA sequences in the serum and PBMC for up to 70 mo after complete resolution of an acute episode of hepatitis B. Biochemical, biophysical, and immunochemical analysis suggests that the serum HBV DNA sequences may be present within intact virions in circulating immune complexes, and that the HBV DNA is transcriptionally active in PBMC long after serological, biochemical, and clinical recovery from acute viral hepatitis.

\section{Methods}

Sera and PBMC. Serum samples were collected sequentially from four individuals (three males and one female; mean age $26 \mathrm{yr}$ ). The first sample was drawn during an acute episode of typical type B hepatitis when serum alanine aminotransferase activity averaged $1,648 \pm 853$ IU/L. Subsequent samples were obtained at various times (between 7 and $70 \mathrm{mo}$ ) after complete clinical, biochemical, and serological recovery from the disease (Table I). At least three serum samples were obtained from each individual. Three of the patients (cases 2, 3, and 4) developed anti-HBs and remained antibody positive for 3-5 yr of follow-up. One patient (case 1) cleared HBsAg but had not yet developed anti-HBs when she was lost to follow-up 7 mo after clinical resolution of her liver disease. PBMC harvested at the end of the observation period were available for examination in three patients. In the remaining patient (case 3), PBMC were obtained 7 mo after disease onset, at the time when anti-HBs was already detectable in the circulation. All individuals investigated were a part of the patient cohort participating in a long-standing study on the cellular immune responses to HBV and they were only patients with self-limited hepatitis B which were followed up for longer than 6 mo after complete clinical, biochemical, and serological recovery from hepatitis.

Serum samples were also collected from a patient with extremely severe acute (fulminant) hepatitis with coma, who spontaneously recovered while awaiting a liver transplant (case 5; Table I). Control sera and PBMC were obtained from two HBV DNA-positive patients with histologically proven chronic active hepatitis B (CAHB) and from three controls with no clinical or serological evidence of $\mathrm{HBV}$ infection.

Serological assays and slot-blot hybridization. HBsAg, anti-HBs, $\mathrm{HBeAg}$, anti-HBe, and anti-HBc of IgM class were detected by conventional solid-phase assays using Ausria II, Ausab EIA, Abbott $\mathrm{HBe}$ (rDNA), and Corab M, respectively (Abbott Laboratories, North Chi- 


\begin{tabular}{|c|c|c|c|c|c|c|c|c|c|c|}
\hline \multirow[b]{2}{*}{ Case No. } & \multirow[b]{2}{*}{$\begin{array}{c}\text { Sex } \\
(\mathrm{F} / \mathrm{M})\end{array}$} & \multirow[b]{2}{*}{ Age } & \multirow[b]{2}{*}{$\begin{array}{l}\text { Clinical } \\
\text { diagnosis }\end{array}$} & \multirow[b]{2}{*}{$\begin{array}{l}\text { Time after } \\
\text { disease onset }\end{array}$} & \multirow[b]{2}{*}{ ALT } & \multirow[b]{2}{*}{ HBsAg* $^{*}$} & \multirow[b]{2}{*}{ anti-HBs ${ }^{\ddagger}$} & \multicolumn{3}{|c|}{ Serum HBV DNA } \\
\hline & & & & & & & & $\begin{array}{c}\text { Slot-blot } \\
\text { hybridization }\end{array}$ & $\begin{array}{l}\text { PCR-EB } \\
\text { agarose" }\end{array}$ & $\begin{array}{l}\text { PCR-Southern } \\
\text { hybridization' }\end{array}$ \\
\hline & & $y r$ & & mo & IU/liter & & & & & \\
\hline \multirow[t]{3}{*}{1} & $\mathrm{~F}$ & 22 & SL-AH & 0.5 & 1638 & + & - & - & + & + \\
\hline & & & & 1 & 28 & - & - & - & + & + \\
\hline & & & & 7 & 12 & - & - & - & + & + \\
\hline \multirow[t]{8}{*}{2} & $\mathbf{M}$ & 35 & SL-AH & 0.5 & 2355 & + & - & + & + & + \\
\hline & & & & 3 & 42 & + & - & - & + & + \\
\hline & & & & 6 & 16 & - & - & - & + & + \\
\hline & & & & 9 & 32 & - & + & - & + & + \\
\hline & & & & 14 & 24 & - & + & - & + & + \\
\hline & & & & 28 & 15 & - & + & - & + & + \\
\hline & & & & 31 & 18 & - & + & - & + & + \\
\hline & & & & 46 & 10 & - & + & - & + & + \\
\hline \multirow[t]{4}{*}{3} & $\mathbf{M}$ & 27 & SL-AH & 0.5 & 450 & + & - & - & + & + \\
\hline & & & & 3 & 29 & - & + & - & + & + \\
\hline & & & & 7 & 21 & - & + & - & + & + \\
\hline & & & & 50 & 23 & - & + & - & + & + \\
\hline \multirow[t]{4}{*}{4} & $\mathbf{M}$ & 22 & SL-AH & 0.5 & 2148 & + & - & + & + & + \\
\hline & & & & 3 & 25 & - & + & - & + & + \\
\hline & & & & 6 & 42 & - & + & - & + & + \\
\hline & & & & 70 & 24 & - & + & - & + & + \\
\hline \multirow[t]{3}{*}{5} & $\mathbf{M}$ & 23 & SL-FH & $1^{* *}$ & 460 & - & - & - & - & - \\
\hline & & & & $1.5^{* *}$ & n.t. & - & + & - & - & - \\
\hline & & & & $3^{\ddagger \pm}$ & 62 & - & - & - & - & - \\
\hline 6 & $\mathbf{M}$ & 31 & САНB & n.a. & 120 & + & - & + & + & + \\
\hline 7 & $\mathbf{M}$ & 39 & САНB & n.a. & 106 & + & - & + & + & + \\
\hline 8 & $\mathrm{~F}$ & 28 & Control & n.a. & 27 & - & - & - & - & - \\
\hline 9 & $\mathbf{M}$ & 26 & Control & n.a. & 12 & - & - & - & - & - \\
\hline 10 & $\mathbf{M}$ & 33 & Control & n.a. & 20 & - & - & - & - & - \\
\hline
\end{tabular}

SL-FH, self-limited fulminant hepatitis B; n.t., not tested; n.a., not applicable.

${ }^{*}$ Evaluated by Ausria II (Abbott Laboratories). ${ }^{\ddagger}$ Evaluated by Ausab EIA (Abbott Laboratories). ${ }^{\S}$ Approximate sensitivity $10^{7}$ genome equivalents/ml. "Amplified by direct or nested PCR with HBV core primers and analyzed in $0.9 \%$ agarose with EB (sensitivity of direct and nested PCR $10^{3}$ and $10^{2}$ genome equivalents/ml, respectively). ' Hybridization to HBC INT probe (approximate sensitivity for detection of direct and nested PCR products $10^{3}$ and between $10^{1}$ and $10^{2}$ genome equivalents/ml, respectively. ** Positive for anti-HBc IgM Corab M (Abbott Laboratories). ${ }^{\ddagger \ddagger}$ Positive for anti-HBe by Abbott HBe (rDNA) assay (Abbott Laboratories).

cago, IL). A slot-blot hybridization test for HBV DNA was performed by the Scripps Immunology Reference Laboratory (La Jolla, CA). The assay limit of HBV DNA detection was determined using 10 -fold serial dilutions of plasmid pFC80 that contains four complete sequences of HBV (ayw subtype) cloned as a head-to-tail tetramer into the EcoRI site of pBR322 (12). The assay sensitivity was $160 \mathrm{pg} \mathrm{HBV} \mathrm{DNA} / \mathrm{ml}$, corresponding to a level of $10^{7}$ genomes $/ \mathrm{ml}$.

Preparation of serum samples for HBV DNA detection. Under most circumstances, $50 \mu \mathrm{l}$ of serum were supplemented with $50 \mu \mathrm{l}$ of TE

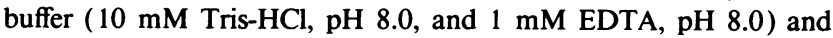
incubated at $42^{\circ} \mathrm{C}$ for $3 \mathrm{~h}$ with proteinase $\mathrm{K}(50 \mu \mathrm{g} /$ reaction $)$ in $200 \mu \mathrm{l}$ of a lysis buffer containing $10 \mathrm{mM}$ Tris- $\mathrm{HCl}, \mathrm{pH} 8.0,10 \mathrm{mM} \mathrm{NaCl}, 1$ mM EDTA, pH 8.0, and 0.5\% SDS. DNA was extracted by the phenolchloroform method, precipitated with sodium acetate-ethanol, washed with $70 \%$ ethanol, and dissolved in $20 \mu$ l of TE buffer. $10 \mu \mathrm{l}$ of DNA sample was used for direct PCR amplification.

Although serum was used as the source of DNA in this study, the influence of different anticoagulants on the detectability of HBV DNA was assessed to determine if plasma samples could also be analyzed for HBV DNA by PCR. For this purpose, blood samples ( $\sim 7 \mathrm{ml}$ each) from the same HBsAg-positive individual with chronic hepatitis type $B$ were collected using vacutainers with no additives (red tops) or containing sodium heparin (green tops), EDTA (lavender tops), and acid citrate dextrose (ACD; yellow tops) (Becton Dickinson, \& Co., Rutherford, NJ). DNA was isolated from $50 \mu \mathrm{l}$ of the resulting serum or plasma as described above.

To differentiate free HBV DNA molecules from virions or HBV core particles, selected serum samples were examined for HBV DNA content before and after extensive digestion with DNAase. For DNAase digestion, $50 \mu \mathrm{l}$ of serum was supplemented with $30 \mu \mathrm{l}$ of deionized water, $10 \mu$ l of DNAase digestion buffer $(500 \mathrm{mM}$ Tris- $\mathrm{HCl}$, $\mathrm{pH} 7.6$, and $100 \mathrm{mM} \mathrm{MgCl}$ ) and $10 \mu \mathrm{l}$ of DNAase solution $(1 \mathrm{mg} / \mathrm{ml}$; deoxyribonuclease I; Sigma Chemical Co., St. Louis, MO) and incubated at $37^{\circ} \mathrm{C}$ for $1 \mathrm{~h}$. Each sample was digested three times to exclude the possibility of carry over of any free HBV DNA. At the end of the first and the second incubation, $10 \mu \mathrm{l}$ of the reaction mixture was re- 
moved and $10 \mu \mathrm{l}$ of fresh DNAase solution was added. After the third incubation, each sample was treated with proteinase $K$, and DNA was extracted as described above. After phenol-chloroform extraction and precipitation with ethanol, DNA was dissolved in $20 \mu \mathrm{l}$ of TE buffer and a $10-\mu 1$ aliquot was analyzed by PCR. Results were compared with similarly treated $\mathrm{HBsAg}$-positive serum from patients with chronic hepatitis, and with plasmid DNA containing the complete HBV genome.

Determination of sedimentation velocity and buoyant density of particles carrying $H B V D N A$. One hundred $\mu \mathrm{l}$ of late convalescent sera from cases 2, 3, and 4 were sedimented through $4 \mathrm{ml}$ of $15 \%$ (wt/vol) sucrose in $\mathrm{TN}$ buffer ( $10 \mathrm{mM}$ Tris- $\mathrm{HCl}, \mathrm{pH} 8.0$, and $140 \mathrm{mM} \mathrm{NaCl}$ ) onto a $0.5-\mathrm{ml} 60 \%$ sucrose cushion. Results were compared with two preparations of purified Dane particles (designated as D.J. and T.R.; generously provided by Dr. J. L. Gerin, Georgetown University, Rockville, MD), and a sample of recombinant plasmid pFC80 containing cloned HBV genome digested with restriction enzyme Sau3AI that were sedimented as controls. All tubes were centrifuged for $4 \mathrm{~h}$ at $40,000 \mathrm{rpm}$ at $5^{\circ} \mathrm{C}$ in an SW60 rotor (Beckman Instruments, Inc., Palo Alto, CA). Fractions of $330 \mu \mathrm{l}$ were collected from the bottom of each tube and sucrose density was determined in a refractometer. From each fraction, a $50-\mu$ l sample was boiled for $5 \mathrm{~min}$ in a water bath and assayed for HBV DNA by PCR. 200- $\mu$ l samples of the fractions were also tested for HBsAg by Ausria II kit (Abbott Laboratories). S/N values were calculated according to the procedure proposed by the manufacturer using relevant sucrose fractions of normal human serum as negative controls.

To determine the density of the serum HBV DNA, $200 \mu \mathrm{l}$ of late convalescent sera collected from cases 2,3 , and 4, control sera from HBV DNA-positive patients with CAHB, and a sample of Sau3AI digested plasmid DNA were layered onto $4.5 \mathrm{ml}$ of continuous gradients of $1.1-1.7 \mathrm{~g} / \mathrm{cm}^{3} \mathrm{CsCl}$ in TE buffer. After centrifugation for $16 \mathrm{~h}$ at $40,000 \mathrm{rpm}$ at $5^{\circ} \mathrm{C}$ in an SW60 rotor, 330- $\mu$ l fractions were collected from the bottom of the tubes. 50- $\mu \mathrm{l}$ samples of those fractions were boiled for $5 \mathrm{~min}$ and tested for HBV DNA by PCR after ascertaining that cesium chloride did not adversely influence HBV DNA detection.

Extraction of DNA and RNA from PBMC. PBMC ( $\sim 2 \times 10^{7}$ cells $)$ isolated on Ficoll-Histopaque density gradients from heparinized blood were cryopreserved in 90\% FCS and 10\% DMSO and stored in liquid nitrogen until use. PBMC were thawed on ice and washed three times by centrifugation at $700 \mathrm{~g}$ for $8 \mathrm{~min}$ with a total of $45 \mathrm{ml}$ of HBSS. The final cell wash was saved as a control for contamination of the PBMC with HBV DNA derived from blood or damaged cells. In complementary experiments, washed PBMC were suspended in $900 \mu \mathrm{l}$ of HBSS containing $100 \mu \mathrm{l}$ of $10 \times$ DNAase digestion buffer and DNAase $(100 \mu \mathrm{g} /$ reaction $)$, incubated at $37^{\circ} \mathrm{C}$ for $1 \mathrm{~h}$, then supplemented with $10 \mu \mathrm{l}$ of $100 \mathrm{mM} \mathrm{CaCl}$ and digested with trypsin $(100 \mu \mathrm{g} /$ reaction; type II; Sigma) for $30 \mathrm{~min}$ on ice. The resulting cells were washed with HBSS.

DNA isolation was performed as previously described (13). $50 \mu \mathrm{l}$ of the isolated DNA was analyzed by PCR in parallel with $50-\mu 1$ samples of the final PBMC wash. Total RNA was extracted from PBMC harvested at 39 and 70 mo from cases 2 and 4, respectively. The cells were homogenized and solubilized according to the acid guanidinum thiocyanate-phenol-chloroform method (14). The final RNA was treated with RNAase-free DNAase I ( $2 \mathrm{U} /$ reaction) (Promega Corp., Madison, WI ) for $30 \mathrm{~min}$ at $37^{\circ} \mathrm{C}$ and then with RNAase $\mathrm{H}(1.5 \mathrm{U} / \mathrm{reac}$ tion) (Bethesda Research Laboratories, Gaithersburg, MD) for $30 \mathrm{~min}$ at $37^{\circ} \mathrm{C}$ to eliminate possible viral RNA/DNA hybrids resistant to DNAase digestion $(15,16)$. The enzymes were subsequently inactivated by incubation at $95^{\circ} \mathrm{C}$ for $5 \mathrm{~min}$ and the RNA stored at $-70^{\circ} \mathrm{C}$.

$P C R$. Two pairs of oligonucleotide primers specific for the HBV core gene and representing sequences conserved among HBV subtypes and an oligonucleotide probe homologous with the fragment internal to these primers were synthesized on a model 308B DNA synthesizer (Applied Biosystems, Inc., Foster City, CA). For control amplifications, external and nested primer pairs specific for the ampicillin resistance $\left(\mathrm{AMP}^{\mathrm{R}}\right)$ gene of plasmid vectors commonly used in our labora- tory and a single-stranded probe internal to these primers (AMP INT) were designed and synthesized. In addition, a primer pair specific for pre-S region (PSU-NSU) was used in selected studies. The characteristics of these oligonucleotides are provided in Table II.

DNA samples derived from sera $(10 \mu \mathrm{l})$ or PBMC $(\sim 1 \mu \mathrm{g})$ were amplified in a $100-\mu$ l reaction volume in a programmable thermal cycler ( TwinBlock System, Ericomp, Inc., San Diego, CA). The reaction mixture was prepared using GeneAmp reagents (Perkin-ElmerCetus, Norwalk, CT) and a procedure proposed by the manufacturer. For amplification with the PCO-COR primer pair ( Table II), the samples were initially denatured at $93^{\circ} \mathrm{C}$ for $5 \mathrm{~min}$, cooled to $52^{\circ} \mathrm{C}$ for 2 min to anneal the primers to the template DNA, and incubated at $70^{\circ} \mathrm{C}$ for $3 \mathrm{~min}$ to allow elongation. Subsequently, the amplification was carried out for 30 cycles. The last cycle was followed by a 3-min elongation step at $70^{\circ} \mathrm{C}$. For the second round of amplification, $10 \mu \mathrm{l}$ of the mixture resulting from the direct reaction was amplified with the PCNNCO pair (Table II) using the same temperature program as that for the direct PCR.

Semiquantitative estimation of the level of HBV DNA in tested samples was done by amplifying 10 -fold serial dilutions of the extracted DNA with the HBV core primers with subsequent detection of PCR products by Southern-blot hybridization to HBC INT probe (Table II). The levels of sensitivity of direct and nested PCRs were determined using 10-fold serial dilutions of cloned HBV genome in normal human serum or TE buffer, followed by hybridization detection of the amplified DNA products. This monitoring revealed that the sensitivity of the direct and nested PCRs employing the HBV core primers was $10^{-3}$ and $10^{-5} \mathrm{pg} \mathrm{HBV} \mathrm{DNA} / \mathrm{ml}$, respectively (corresponding to $\sim 10^{3}$ and between $10^{1}$ and $10^{2}$ genome equivalents $/ \mathrm{ml}$ ). The nested PCR amplification with $\mathrm{AMP}^{\mathrm{R}}$ primers, coupled with hybridization analysis, could detect $\sim 10^{-5} \mathrm{pg}$ of pBR322 DNA/ml (equivalent to about $10-100$ copies $/ \mathrm{ml}$ ).

Amplifications with primers specific for the HBV pre-S region and $A M P^{R}$ gene were carried out for 40 cycles. The reaction mixture was heated to $94^{\circ} \mathrm{C}$ for $1 \mathrm{~min}$, cooled to $58^{\circ} \mathrm{C}$ for $1 \mathrm{~min}$, and then heated to $72^{\circ} \mathrm{C}$ for $1 \mathrm{~min}$. Final elongation was done at $72^{\circ} \mathrm{C}$ for $5 \mathrm{~min}$. The sensitivity of direct PCR using the HBV pre-S primers and ethidium bromide (EB)-agarose detection was $\sim 10^{-2} \mathrm{pg} \mathrm{HBV} \mathrm{DNA} / \mathrm{ml}$ (equivalent to about $10^{4}$ copies $/ \mathrm{ml}$ ).

To eliminate sources of DNA contamination, rigorous precautions were taken. All sera and PBMC samples were divided into small aliquots under sterile conditions in a laminar flow hood using disposable plasticware before bringing them to the laboratory where they were handled separately from PCR products, bacterial plasmids, and other possible sources of HBV DNA contamination. Each sample was analyzed by PCR at least twice. In the cases of positive HBV DNA identification, DNA isolated from a newly opened aliquot of the same serum or PBMC sample was amplified to confirm the positive result. All amplifications were performed in parallel with relevant negative and positive controls which consisted of DNA derived from the sera and/or PBMC of healthy individuals and HBV-positive patients. Positive controls also included amplification of recombinant HBV DNA of the $a y w$ subtype derived from plasmid pFC80. Contamination controls consisted of water added to the PCR mixture instead of DNA. All reagents and buffers used during DNA isolation and PCR amplification were periodically assayed for the presence of viral DNA contamination. To further confirm validity of HBV DNA identification, samples positive for HBV DNA were subjected to nested PCR amplification using primers specific for plasmid $A M P^{R}$ gene (Table II). In addition, since the laboratory plasmids carry HBV ayw genomes only, amplification of the HBV DNA positive samples with primers specific for the pre-S region was performed to help verify the authenticity of the detected DNA by assessing divergence in the molecular size between the $a d$ and ay subtypes of the virus.

Reverse transcriptase PCR. Approximately $1 \mu \mathrm{g}$ of RNA derived from each PBMC preparation was used for CDNA synthesis. The reaction was performed using cDNA Synthesis System Plus (Amersham 


\begin{tabular}{|c|c|c|c|}
\hline & Sequence & Position & $\begin{array}{l}\text { Expected size o } \\
\text { target sequence }\end{array}$ \\
\hline & & & $b p$ \\
\hline \multicolumn{4}{|l|}{ HBV C-ORF specific } \\
\hline \multicolumn{4}{|l|}{ External primers } \\
\hline PCO (sense) & 5'-CTGGGAGGAGTTGGGGGA & $1732-1750^{*}$ & 723 \\
\hline COR (antisense) & 5'-CTAACATTGAGATTCCCGA & $2454-2436^{*}$ & \\
\hline \multicolumn{4}{|l|}{ Nested primers: } \\
\hline PCN (sense) & 5'-CTGTAGGCATAAATTGGT & $1783-1800^{*}$ & 554 \\
\hline NCO (antisense) & 5'-TCCGGAAGTGTTGATA & $2336-2321^{*}$ & \\
\hline \multicolumn{4}{|l|}{ Probe: } \\
\hline HBC INT (sense) & 5'-CCTCACCATACAGCACTCAGGCAA & $2050-2073^{*}$ & 723 or 554 \\
\hline \multicolumn{4}{|l|}{ HBV S-ORF specific } \\
\hline \multicolumn{4}{|l|}{ Primers: } \\
\hline PSU (sense) & 5'-GGGTCACCATATTCTTGGGA & $2816-2835^{*}$ & \\
\hline NSU (antisense) & 5'-GTCCTAGGAATCCTGATG & $187-170^{*}$ & $\geqslant 554^{\ddagger}$ \\
\hline \multicolumn{4}{|c|}{ Plasmid AMPR gene specific } \\
\hline \multicolumn{4}{|l|}{ External primers } \\
\hline PPAC (sense) & 5'-CTCAGCGATCTGTCTATTTCGTTCA & $3324-3348^{\ddagger}$ & \\
\hline XMNG (antisense) & 5'-GCCCCGAAGAACGTTTTCCAATGATGAG & $3979-3952^{\ddagger}$ & 656 \\
\hline \multicolumn{4}{|l|}{ Nested primers } \\
\hline PPPA (sense) & 5'-ACTACGATACGGGAGGGCTTACCATCG & $3382-3408^{\ddagger}$ & \\
\hline XXMN (antisense) & 5'-ATCCCGTGTTGACGCCGGGCAAGAGCA & $3918-3882^{\ddagger}$ & 537 \\
\hline \multicolumn{4}{|c|}{ ( } \\
\hline AMP INT (sense) & 5'-CGTTTGGTATGGCTTCATTCAG & $3635-3656^{\ddagger}$ & 537 or 656 \\
\hline
\end{tabular}

* Numbers denote the position of the sequence in HBV ayw (39), with the exception of position 2061 in HBC INT probe were threonine (T) was replaced with alanine (A), since this last nucleotide is more frequently accounted within sequences of different $\mathrm{HBV}$ subtypes. ${ }^{\ddagger}$ Numbers denote the position of the sequence in pBR322 (40).

Corp., Arlington Heights, IL). As controls, RNA samples derived from the same PBMC but treated with DNAase and then RNAase A ( 100 $\mu \mathrm{g} / \mathrm{ml}, 1 \mathrm{~h}$ at $37^{\circ} \mathrm{C}$; ribonuclease A, Sigma Chemical Co.) were used. Additional negative controls included water instead of RNA and omission of oligo-dT primer and reverse transcriptase during cDNA synthesis. HBV-specific sequences were amplified using nested PCR and core specific primers.

Detection of amplified DNA. Twenty $\mu$ l aliquots of the products from direct or nested PCR amplifications were analyzed by electrophoresis on a $0.9 \%$ agarose gel in the presence of $0.5 \mu \mathrm{g} / \mathrm{ml}$ of EB. DNA bands were visualized by ultraviolet fluorescence. For Southern-blot analysis, the PCR-amplified DNA was transferred by capillary transfer to a nylon membrane (Hybond-N; Amersham Corp.) and hybridized to ${ }^{32} \mathrm{P}$-labeled HBC INT or AMP INT probe (17). The membranes were exposed to X-ray film (XAR; Eastman Kodak Co., Rochester, $\mathrm{NY}$ ) with an intensifying screen.

\section{Results}

HBV DNA in Sera of individuals convalescent from acute hepatitis $B$. HBsAg was detected in sera obtained during the acute phase of SL-AH in all individuals studied, but not in the samples collected following resolution of the disease (Table I). All but two of the acute phase sera and all of the convalescent phase sera were negative for HBV DNA by slot-blot hybridization (sensitivity $\sim 10^{7}$ genome equivalents $/ \mathrm{ml}$ ). The same sera, examined by nested PCR using the HBV core primers and detection of PCR products by EB-agarose or Southern-blot hybridization (sensitivity $10^{2}$ and between $10^{1}$ and $10^{2}$ genome equivalents $/ \mathrm{ml}$, respectively), revealed the persistent presence of HBV DNA long after recovery in all individuals studied, except in a patient with fulminant hepatitis (case 5) in whom the only detectable markers of $\mathrm{HBV}$ infection at the time of clinical presentation were antibodies to $\mathrm{HBs}, \mathrm{HBe}$, and $\mathrm{HBc}$ antigens (Table I, legend). It is noteworthy that HBV DNA was detected at intervals as long as $7,43,50$, and 70 mo after resolution of all conventional parameters of disease in the patients whose sera were available for study. Interestingly, HBV DNA coexisted with anti-HBs in three of these cases for as long as 37-67 mo (cases 2, 3, and 4; Table I).

Surprisingly, semiquantitative evaluation of HBV DNA using serial dilutions of the serum-derived DNA revealed that the level of viral DNA did not decrease dramatically between the earliest and the last samples (Fig. 1). In fact, concentrations of serum HBV DNA remained apparently unchanged in one individual after 7 mo of follow-up (about $10^{4}$ genome equivalents/ $\mathrm{ml}$; case 1 ), whereas the remaining three patients decreased 10-100-fold during a mean observation interval of $55.3 \mathrm{mo}$ (cases 2, 3, and 4) at which time the serum contained between $10^{2}$ and $10^{3}$ genome equivalents $/ \mathrm{ml}$.

The possibility that the sera were contaminated by exogenous PCR products or exogenous plasmid DNA was excluded by the inclusion of negative control sera and contamination controls in all assays and by the failure of HBV DNA positive samples to react with primers specific for the $p B R 322$ AMP $^{R}$ gene by nested PCR and Southern-blot hybridization (data not 
Case 1

$0.5 \mathrm{mo}$

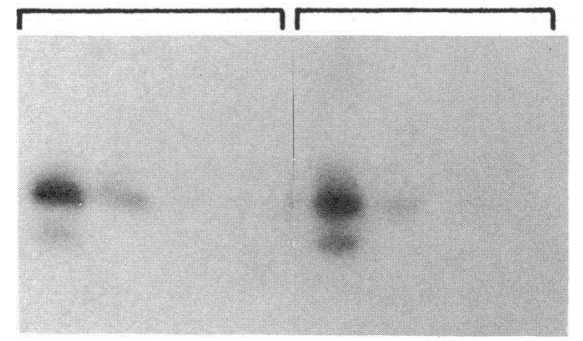

$10^{-2} 10^{-3} 10^{-4} 10^{-5} 10^{-2} 10^{-3} 10^{-4} 10^{-5}$

Case 3

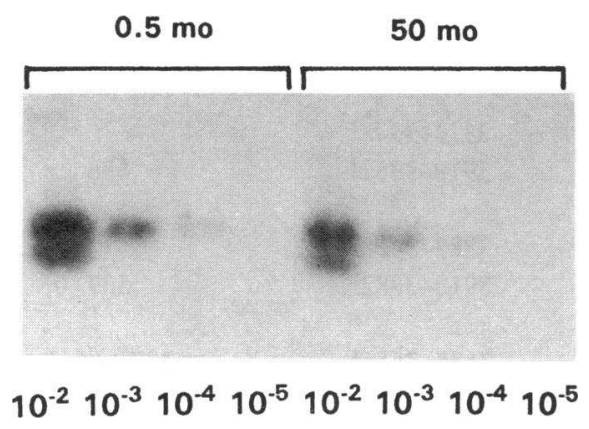

Case 2

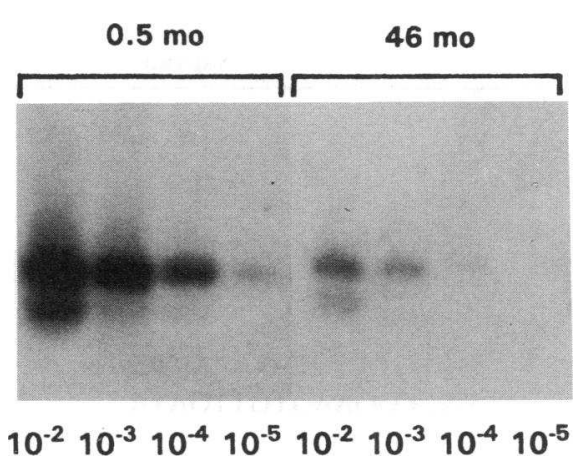

Case 4

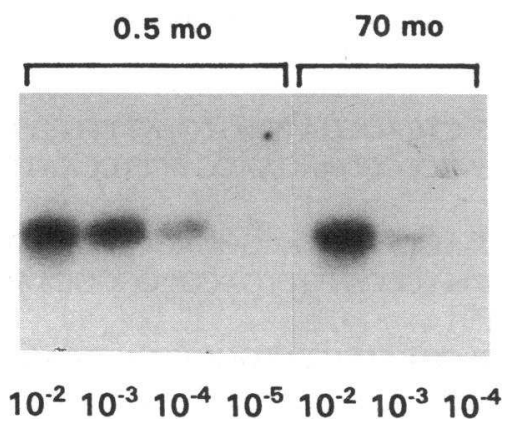

Figure 1. Quantitation of HBV DNA in serum samples obtained during the acute episode and at the end of follow-up from individuals convalescent from acute hepatitis B. 10-fold dilutions of DNA isolated from the equivalent of $100 \mu$ l of serum were amplified by direct PCR with $\mathrm{HBV}$ core region primers and products identified by Southern-blot hybridization to HBC INT probe. shown ). Furthermore, amplification with pre-S region primers of the DNA isolated from sera harvested at the end of the follow-up period in cases 1-4 and the HBV plasmids present in our laboratory (ayw subtype), produced DNA fragments of 587 and 554 bp, respectively (data not shown). Size differences between the HBV DNA fragments amplified from the sera and those from the plasmids further eliminated the possibility of false positive results due to plasmid contamination, confirming the validity of the HBV DNA identification in convalescent sera. In addition, the analysis suggested that these patients were most likely infected with the $a d w$ subtype of $\mathrm{HBV}$ which is the most common subtype in North America (18).

Nested PCR with HBV core specific primers and Southernblot analysis of DNAs isolated from serum and plasma obtained at the same time point from an $\mathrm{HBV}$-infected patient revealed that heparinization of blood interferes with the subsequent detection of HBV DNA by the PCR procedure described herein, while anticoagulation with EDTA or ACD does not (Fig. 2). This observation has been confirmed using woodchuck hepatitis virus DNA positive serum and plasma (19).

Biochemical and biophysical characterization of $\mathrm{HBV}$ DNA-positive particles. To determine if the HBV DNA might be present within intact virions, acute and convalescent serum samples were subjected to sequential DNAase and proteinase $\mathrm{K}$ digestion before isolation of DNA. Extensive DNAase treatment of the samples did not abolish HBV DNA reactivity in any of the sera, but some of the digested samples gave a distinctly weaker hybridization signal (Fig. $3 \mathrm{~A}$ ). The same treatment of plasmid DNA completely eliminated HBV DNA reactivity, as determined by Southern-blot hybridization of PCR products (Fig. $3 A$ ). DNAase resistant HBV DNA displayed DNAase sensitivity following digestion with proteinase $\mathrm{K}$ (Fig. $3 B$ ), suggesting that the HBV DNA was encased within a protective layer of protein as would occur in a virus particle.

To investigate whether the HBV DNA-protein complexes displayed physicochemical characteristics of circulating virions, late convalescent serum samples from cases 2,3 , and 4 were centrifuged through $15 \%$ sucrose in parallel with purified Dane particles and recombinant HBV DNA, and the resulting fractions were tested for HBV DNA and HBsAg. In all three convalescent sera the HBV DNA sedimented to fractions 2 to 5 compared with fractions 2 and 3 for the purified Dane particles (Fig. 4). In contrast, the peak of free HBV DNA reactivity originating from plasmid DNA was detected in fractions 8-11. In view of the prolonged storage of most of the samples, these results are compatible with the presence of partially denaturated virions, which would also explain the partial DNAase sensitivity of the samples as illustrated in Fig. 3.

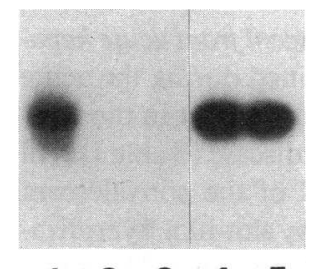

$\begin{array}{lllll}1 & 2 & 3 & 4 & 5\end{array}$
Figure 2. Effect of anticoagulants on the detection of HBV DNA by PCR. DNA isolated from the equivalent of $25 \mu \mathrm{l}$ of serum (lane 1 ) or $25 \mu \mathrm{l}$ of plasma obtained from heparinized blood (lanes 2 and 3) or blood treated with EDTA (lane 4) or ACD (lane 5) from the same HBsAg-positive patient were amplified by direct (lanes 1,2 and 4,5 ) or nested (lane 3) PCR with HBV core specific primers. Viral DNA was detected by Southern-blot hybridization to HBC INT probe. 


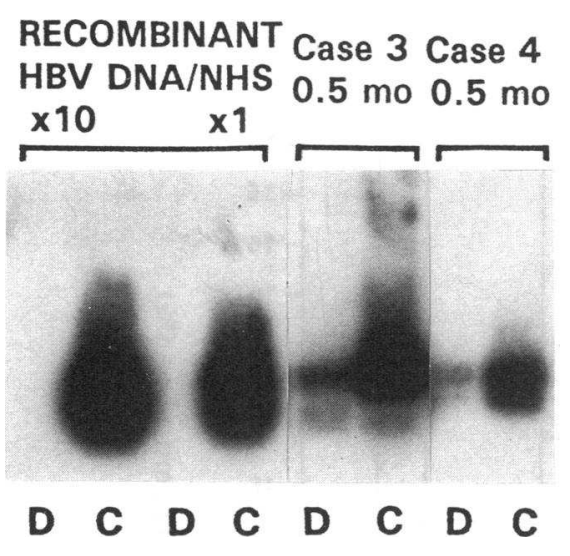

\section{A}

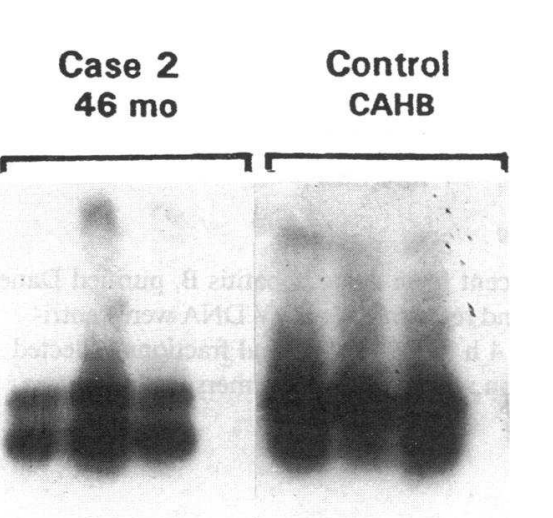

\section{$\begin{array}{llllllll}1 & 2 & 3 & 4 & 1 & 2 & 3 & 4\end{array}$}

Figure 3. Effect of enzymatic digestion on the detection of HBV DNA derived from cloned $\mathrm{HBV}$ genome (plasmid pFC80) and in sera of individuals with a history of acute hepatitis B. $(A)$ Plasmid pFC80 suspended in $50 \mu$ l of normal human serum $(N H S)$ at concentrations of $4.7 \mathrm{pg}(\times 10)$ and $0.47 \mathrm{pg}$ of HBV DNA $(\times 1)$ and $50 \mu \mathrm{l}$ of serum obtained during an acute episode of hepatitis from cases 3 and 4 were subjected to triple digestion with DNAase $(D)$ or not treated with DNAase $(C)$ before DNA isolation. $(B) 50-\mu l$ samples of serum obtained at 46 mo of follow-up from case 2 and serum of a patient with chronic active hepatitis $\mathrm{B}(C A H B)$ were subjected to triple DNAase digestion (lane 1), triple DNAase digestion followed by proteinase $\mathrm{K}$ digestion (lane 2), single proteinase $\mathrm{K}$ digestion (lane 3), and triple DNAase digestion followed by proteinase $K$ digestion and single DNAase digestion (lane 4) before DNA isolation. Viral DNA was amplified by nested PCR with HBV core primers and identified by Southern-blot hybridization to HBC INT probe.

Analysis of the same sucrose fractions for $\mathrm{HBsAg}$ revealed trace amounts of antigen in fractions 1-3 in two of the three convalescent sera (Fig. 4) despite the fact that the same unfractionated convalescent sera were anti-HBs positive and $\mathrm{HBsAg}$ negative. In convalescent serum from case 3 , trace amounts of HBsAg co-sedimented with HBV DNA in fractions 2 and 3, similar to the location of the peak of HBsAg reactivity observed in parallel experiments with purified Dane particles, and HBsAg-positive serum from a patient with CAHB (Fig. 4).
These observations suggest that the HBV DNA detectable in late convalescent sera is probably present in a particle that displays the sedimentation velocity of virions and co-sediments with HBsAg. Since these sera are positive for anti-HBs, it is possible that the HBV DNA is present within circulating immune complexes.

The late convalescent sera were also subjected to cesium chloride isopycnic density gradient centrifugation in parallel with $\mathrm{HBsAg}$-positive serum from two patients with chronic hepatitis, and purified HBV plasmid DNA (Fig. 5). PCR analysis demonstrated that serum HBV DNA banded at a mean density of $1.36 \mathrm{~g} / \mathrm{cm}^{3}$ in three of the four patients tested. In the remaining patient (case 3 ) and in two controls chronically infected with $\mathrm{HBV}$, viral DNA banded at a mean density of 1.20 $\mathrm{g} / \mathrm{cm}^{3}$. In contrast, the peak density of recombinant $\mathrm{HBV}$ DNA digested with Sau3AI, used as a source of protein-free virus DNA molecules, was found in fractions with a mean density of $1.72 \mathrm{~g} / \mathrm{cm}^{3}$.

$H B V D N A$ and RNA in PBMC. Nested PCR amplification with $\mathrm{HBV}$ core primers and subsequent Southern-blot hybridization demonstrated the expected 554-bp fragment of $\mathrm{HBV}$ DNA in all examined PBMC samples collected from four patients convalescent from acute infection (Fig. 6). Two of these individuals (cases 2 and 4) had detectable HBV DNA in PBMC obtained at 36 and 70 mo of follow-up, respectively. In one patient (case 4), the HBV DNA was detected in three consecutive samples collected at 6,32 , and 70 mo. Hybridization signals displayed by the DNA derived from comparable numbers of PBMC from these samples were approximately of the same intensity. Amplification of DNA isolated from PBMC of the control patient chronically infected with HBV produced HBV DNA fragments of the same size as those detected in PBMC of convalescent patients. DNA from PBMC of an uninfected control and an aliquot of the last wash from the PBMC isolation procedure did not contain detectable HBV DNA reactivity except for a single specimen (case 2) where a weak signal of residual HBV DNA reactivity was seen (Fig. 6). Treatment of intact PBMC with DNAase followed by trypsin before DNA isolation had no effect on the HBV DNA signal in PBMC (data not shown).

Specific HBV RNA sequences were detected by RT-PCR analysis in two PBMC preparations obtained at 39 and 70 mo from cases 2 and 4, respectively. Hybridization signals were detected after pretreatment of the RNA extracts with DNAase and RNAase $\mathrm{H}$ excluding the possibility of contamination with viral DNA and DNA/RNA hybrids. No amplification products were obtained when the same RNA samples were pretreated with DNAase and then with RNAase A or when oligo$\mathrm{dT}$ primers or reverse transcriptase were omitted during cDNA synthesis (Fig. 7).

\section{Discussion}

This study demonstrates that HBV DNA can persist in the serum and remain transcriptionally active in PBMC for several years after complete serological and clinical resolution of acute viral hepatitis. It corroborates previous reports of persistent HBV DNA sequences in the liver of a single patient with a history of apparently transient viral hepatitis (3), in the liver of a chimpanzee following recovery from acute viral hepatitis due to HBV (20), and in the liver and PBMC in woodchucks conva- 


\begin{tabular}{|c|c|c|c|c|c|c|}
\hline $\begin{array}{l}\text { Case } 2 \\
46 \text { mo }\end{array}$ & $\begin{array}{l}\text { Case } 3 \\
50 \text { mo }\end{array}$ & $\begin{array}{l}\text { Case } 4 \\
70 \text { mo }\end{array}$ & $\begin{array}{l}\text { Purified } \\
\text { Dane } \\
\text { particles } \\
\text { (D.J.) }\end{array}$ & $\begin{array}{c}\text { Purified } \\
\text { Dane } \\
\text { particles } \\
\text { (T.R.) }\end{array}$ & $\begin{array}{c}\text { HBsAg } \\
\text { (CAHB serum) }\end{array}$ & $\begin{array}{c}\text { Recombinant } \\
\text { HBV DNA }\end{array}$ \\
\hline
\end{tabular}

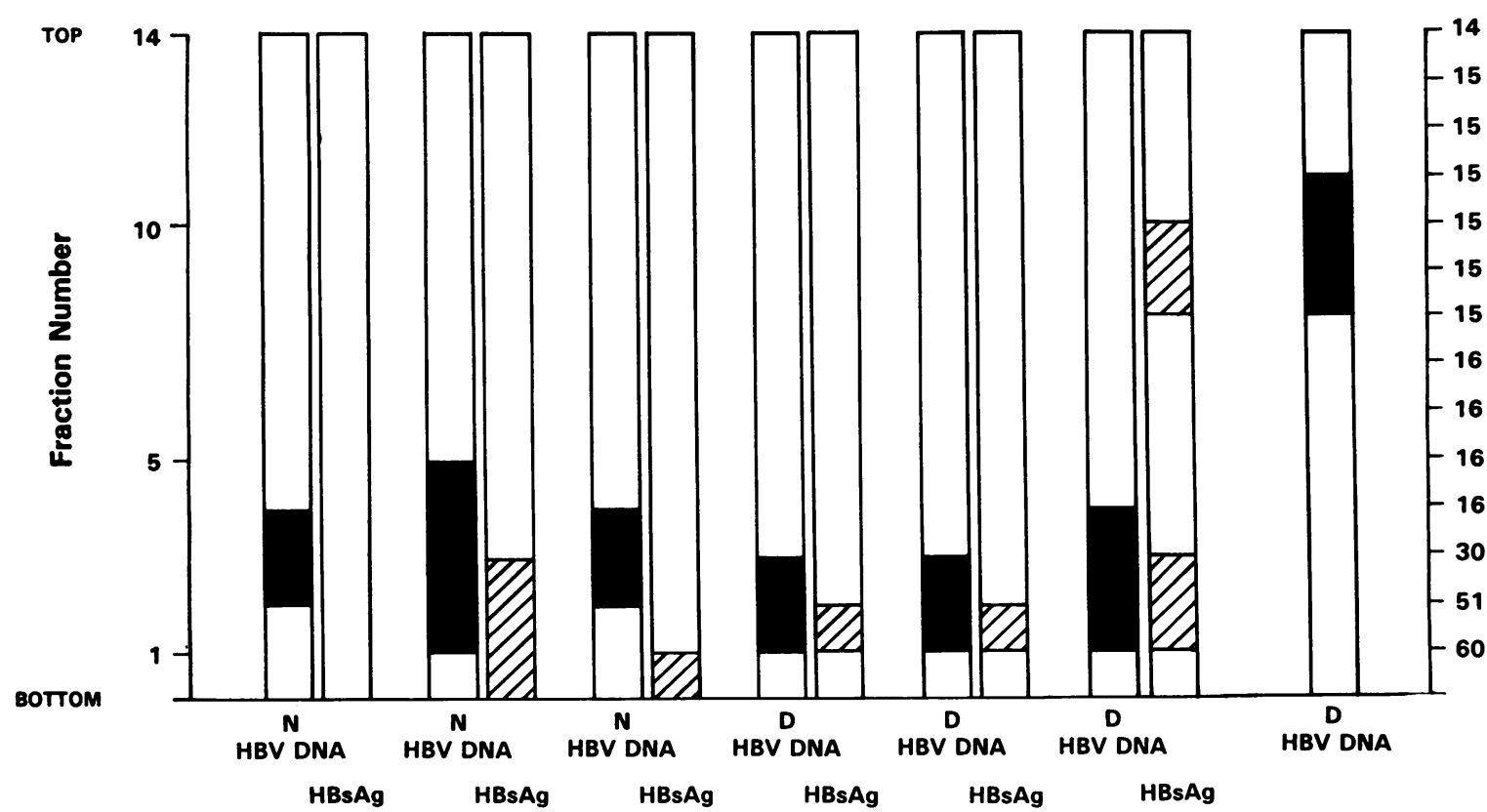

๖̊

Figure 4. Sedimentation velocity of $\mathrm{HBV}$ DNA and HBsAg in sucrose. Sera of individuals convalescent from acute hepatitis B, purified Dane particle preparations, $\mathrm{HBsAg}$-positive serum from a patient with chronic active hepatitis $\mathrm{B}(C A H B)$, and recombinant $\mathrm{HBV}$ DNA were centrifuged through $4 \mathrm{ml}$ of $15 \%$ sucrose onto a $60 \%$ sucrose cushion at $40,000 \mathrm{rpm}$ in an SW60 rotor for $4 \mathrm{~h}$ at $5^{\circ} \mathrm{C}$ and $330-\mu l$ fractions collected from the bottom. HBV DNA reactivity was determined by direct $(D)$ or nested $(N)$ PCR amplification with HBV core primers in EB-agarose (solid bars) and positiveness of HBsAg tested by Ausria II (Abbott Laboratories) (hatched bars).

Case 1 Case 2 Case 3 Case 4 7 mo 46 mo 50 mo 70 mo
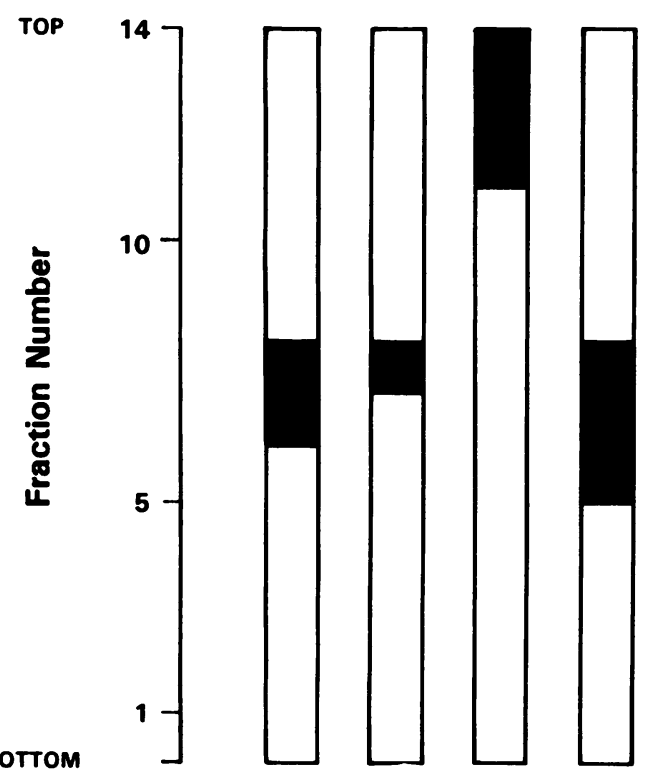

Control Recombinant CAHB sera HBV DNA
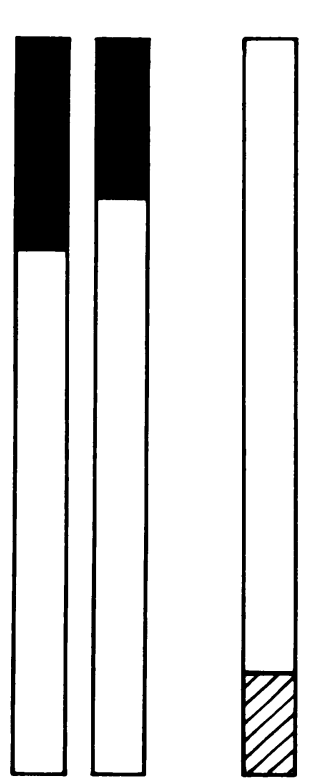

Peak density:

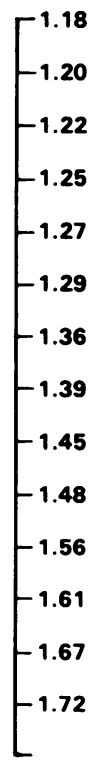

$$
\text { Peak density. }
$$

Figure 5. Isopycnic banding of serum HBV DNA in individuals convalescent from acute hepatitis B and from control sera and recombinant HBV DNA in cesium chloride density gradients. Sample was centrifuged through a $1.1-1.7-\mathrm{g} / \mathrm{cm}^{3}$ gradient at $40,000 \mathrm{rpm}$ in an SW60 rotor, for 16 $h$ at $5^{\circ} \mathrm{C}$, and $330-\mu l$ fractions collected from the bottom. HBV DNA reactivity determined using nested PCR amplification with HBV core primers in EB-agarose (solid bars) or location of the peak reactivity using dilutions of the PCR product (hatched bars). On the right side of the figure, location of the approximate peak densities previously reported for the purified Dane particles and core HBV DNA-positive particles (24) and free HBV DNA in the gradient is displayed. 


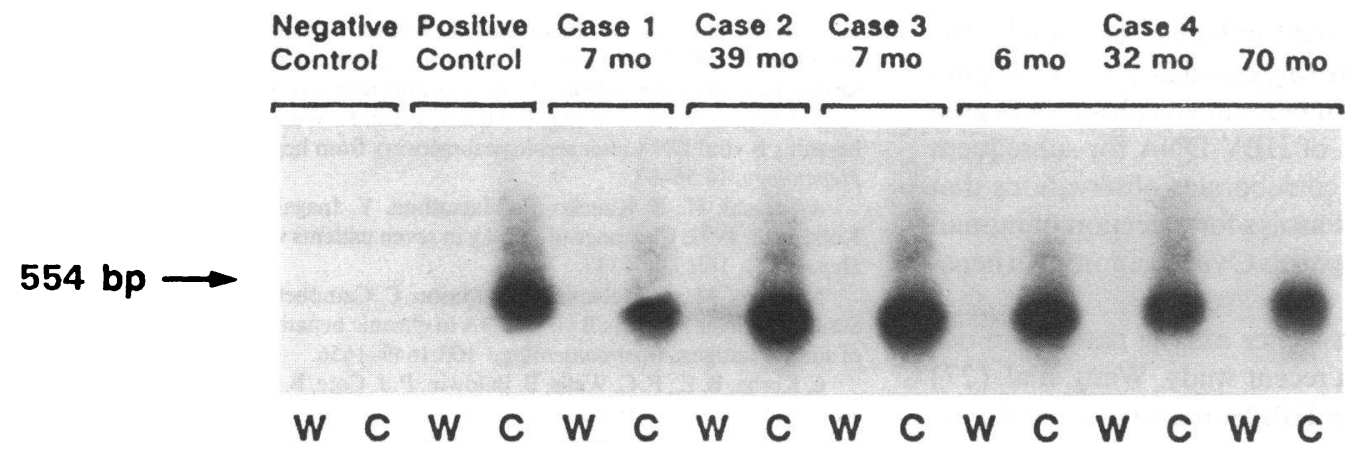

Figure 6. Southern-blot identification of HBV DNA in PBMC of individuals convalescent from acute hepatitis B. DNA from an aliquot of final PBMC wash $(W)$ and $\operatorname{PBMC}(C)$ from a healthy individual (negative control), a patient with CAHB (positive control ) and cases 1-4 were amplified by nested PCR with HBV core primers and hybridized to HBC INT probe. Positive samples show the expected amplified 554bp nucleotide fragment noted by arrow. lescent from acute hepatitis due to WHV (6). These results are also consistent with reports that HBV DNA can persist in the serum after spontaneous or therapeutically induced clearance of $\mathrm{HBs} \mathrm{Ag}$ in patients and woodchucks with chronic hepadnavirus infection (4-11, 21, 22). The current report also demonstrates that the viral DNA appears to be packaged within viruslike particles and it suggests that it may exist within viral particles in the context of immune complexes in the anti-HBs-positive sera.

In the present study, the levels of serum DNA showed a tendency to decline over time, but the rate of decrease was very slow. This finding raises the possibility that persistence of $\mathrm{HBV}$ DNA after an uncomplicated episode of SL-AH may extend much beyond the time-frame examined in our study. The only patient in our study group whose serum samples were negative during convalescence had fulminant hepatitis $\mathrm{B}$ and displayed early anti-HBs, anti-HBe, and anti-HBc IgM responses (case 5 ). This may suggest that complete virus clearance can occur in acute HBV infection in the context of an exceptionally strong antiviral immune response.

Biochemical analysis of the HBV DNA sequences derived from sera obtained at the end of follow-up of individuals convalescent from acute hepatitis B showed that in all four cases a fraction of the DNA molecules was resistant to extensive

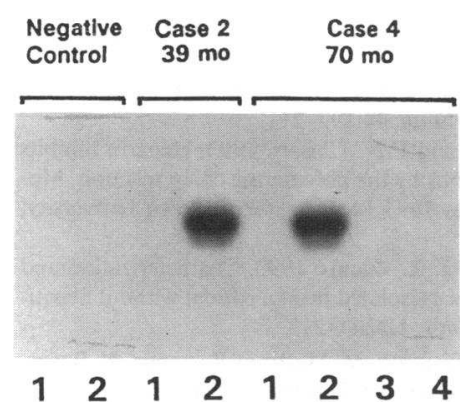

Figure 7. Identification of HBV RNA sequences in PBMC of individuals with long after recovery from SL-AH. Total RNA prepared from PBMC of a healthy individual (negative control) and from patients 2 and 4 were digested with DNAase and RNAase A (lane 1 ) or DNAase and RNAase $\mathrm{H}$ (lane 2) before cDNA synthesis. Control

experiments performed on DNAase- and RNAase H-treated PBMC RNA from patient in which cDNA synthesis was done either in the absence of oligo-dT primer (lane 3) or reverse transcriptase (lane 4). The cDNA was amplified using nested PCR with HBV core primers and the PCR products were detected by Southern-blot hybridization to HBC INT probe.
DNAase treatment unless the serum was first digested with proteinase $\mathrm{K}$. This property was comparable to that observed in HBV DNA positive sera collected during the acute disease from the same individuals and in a control HBV DNA-positive serum derived from a patient with CAHB. This implies that the DNAase resistant HBV DNA molecules are protected by protein and might suggest the presence of circulating intact viral particles. Ultracentrifugation of the HBV DNA-positive convalescent sera indicated that the DNA migrated with a sedimentation velocity similar to that of purified Dane particles in all three individuals examined. Surprisingly, we were also able to detect $\mathrm{HBsAg}$ reactivity (albeit in trace amounts) in sucrose fractions of two of the sera, despite the fact that the unfractionated sera were $\mathrm{HBsAg}$ non-reactive and contained anti-HBsspecific antibodies. This is could be interpreted as direct evidence that $\mathrm{HBV}$ envelope proteins, not only viral DNA, are persistently produced in anti-HBs-positive patients convalescent from acute hepatitis $\mathrm{B}$, suggesting that the viral genome is transcriptionally and translationally active long after clinical, serological, and biochemical recovery from this infection. This is also consistent with the possibility that HBV DNA-positive viral particles are present in these patients probably within immune complexes. The presence of $\mathrm{HBsAg}$ in apparently HBsAg-negative, anti-HBs-positive sera has been previously described, using an assay employing high-affinity monoclonal antibodies to HBsAg (23).

Further analysis of the biophysical properties of the HBV DNA present in the late convalescent sera from 3 of the 4 patients, using isopyknic cesium chloride density gradients revealed that it banded at a mean density of $1.36 \mathrm{~g} / \mathrm{cm}^{3}$, which is comparable with the density of dense HBV core particles (24). In the remaining patient (case 3 ), and in two chronically infected controls, the HBV DNA banded at a mean density of $1.20 \mathrm{~g} / \mathrm{cm}^{3}$, which is compatible with the density of intact Dane particles (24). Since the serum HBV DNA from the same patient co-migrated in sucrose gradients with $\mathrm{HBsAg}$ (Fig. 4), it would appear that the DNA is packaged within native viruslike particles, at least in this case. In view of the partial DNAase sensitivity of the HBV DNA present in some of these sera, it is possible that the high density HBV DNA actually reflects the presence of viral particles that may have been damaged during prolonged storage. Obviously, further studies will be required to establish the precise nature of the HBV DNA containing particles in these convalescent sera, to deter- 
mine if they are infectious and if they contribute to sustained immunity to $\mathrm{HBV}$ in this patient population.

At this point, it is important to emphasize that heparin exerts a dramatic inhibitory effect on the subsequent detection of HBV DNA by PCR. This could influence profoundly the outcome of such studies, and it suggests that previously published data should be reassessed if heparinized plasma was used as a starting point for isolation of HBV DNA for subsequent analysis by PCR. This finding corroborates observations that heparin interferes with the PCR assays for detection of human immunodeficiency virus and hepatitis $C$ virus genomes in heparinized plasma $(25,26)$.

The rate of HBV DNA persistence among patients in our study group is high ( $80 \%$ ). In a recent study, Wang et al. (27) tested plasma samples from $206 \mathrm{HBsAg}$-negative patients, the majority with serologically documented prior $\mathrm{HBV}$ infection, for HBV DNA by direct PCR. Only $4 \%$ of the patients proved to be positive for HBV DNA in that study. The discrepancy between our results and theirs could be due to sample size, or it might reflect our use of serum instead of anticoagulated plasma, as well as differences the sensitivity between nested and direct PCR assays, and in the interval between onset of infection and the collection of the tested samples (not defined by Wang et al. [27]). Obviously, additional studies will be required to clarify the true incidence of persistent $\mathrm{HBV}$ infection after resolution of liver disease, as well as duration of persistence.

Our findings also clearly demonstrate the prolonged persistence of HBV DNA in PBMC after resolution of acute hepatitis $B$ in all four cases studied. Further, we demonstrated the presence of HBV RNA in PBMC collected from two of these patients after more than 3 or 5 yr of follow-up. These results suggest that HBV transcription can occur in human PBMC in the context of serological immunity to $\mathrm{HBV}$, years after resolution of hepatitis.

Identification of HBV specific RNA in the PBMC of our patients is consistent with previous reports that hepadnavirus DNA, RNA and protein are detectable in human and woodchuck PBMC even in the absence of serologic evidence of ongoing virus infection $(11,13,16,28-36)$. Since infectious WHV is produced by mitogen-stimulated PBMC from chronically infected woodchucks $(37,38)$ it is possible that these human cells may also be able to support HBV replication and, thus, serve as a reservoir for cell-to-cell transmission of the virus despite the presence of neutralizing anti-HBs.

Finally, these observations may also have important epidemiological and pathogenetic implications, especially if the HBV DNA-containing particles prove to be infectious, and if viral persistence in PBMC reflects its persistence in the liver or elsewhere in these patients, where it might contribute to the development of chronic diseases that are currently not known to be caused by HBV.

\section{Acknowledgments}

The authors thank Dr. John L. Gerin (Georgetown University, Rockville, MD) for providing preparations of purified Dane particles.

This work was supported by U.S. Public Health Service grants AI20001 and RR-00833. T. I. Michalak was a recipient of a Visiting Scientist Award from the Medical Research Council of Canada and supported in part by the Medical Research Council of Canada research grant MT-11262.

\section{References}

1. Krugman, S., L. R. Overby, L. K. Mushahwar, C. Ling, G. G. Frosner, and F. Deinhardt. 1979. Viral hepatitis, type B: Studies on natural history and prevention re-examined. N. Engl. J. Med. 300:101-106.

2. Blum, H. E., W.-B. Offensperger, F. Walter, S. Offensperger, and W. Gerok. 1988. Latent hepatitis $B$ virus infection with full-length viral genome in a patient serologically immune to hepatitis B virus infection. Liver. 8:307-316.

3. Blum, H. E., T. J. Linag, E. Galun, and J. R. Wands. 1991. Persistence of hepatitis B viral DNA after serological recovery from hepatitis B virus infection. Hepatology. 14:56-63.

4. Adachi, H., S. Kaneko, E. Matsushita, Y. Inagaki, M. Unoura, and K. Kobayashi. 1992. Clearance of $\mathrm{HBsAg}$ in seven patients with chronic hepatitis B. Hepatology. 16:1334-1337.

5. Kuhns, M., A. McNamara, A. Mason, C. Campbell, and R. Perrillo. 1992 Serum and liver hepatitis B virus DNA in chronic hepatitis B after sustained loss of surface antigen. Gastroenterology. 103:1649-1656.

6. Korba, B. E., F. C. Wells, B. Baldwin, P. J. Cote, B. C. Tennant, H. Popper, and J. L. Gerin. 1989. Hepatocellular carcinoma in woodchuck hepatitis virus-infected woodchucks: presence of viral DNA in tumor tissue from chronic carriers and animals serologically recovered from acute infection. Hepatology. 9:461470.

7. Carman, W. F., S. Dourakis, P. Karayiannis, M. Crossey, R. Drobner, and H. C. Thomas. 1991. Incidence of hepatitis B viraemia, detected using the polymerase chain reaction, after successful therapy of hepatitis B virus carriers with interferon- $\alpha$. J. Med. Virol. 34:114-118.

8. Xu, J., D. Brown, T. Harrison, Y. Lin, and G. Dusheiko. 1992. Absence of hepatitis $B$ virus precore mutants in patients with chronic hepatitis $B$ responding to interferon- $\alpha$. Hepatology. 15:1002-1006.

9. Mutchnick, M. G., J. L. Jaurequi, and D. A. Shafritz. 1992. Sustained response to thymosin therapy in patients with chronic hepatitis B. Hepatology. 16:66a. (Abstr.)

10. Molina, J., J. Bartolome, G. Moraleda, M. Riuz-Moreno, M. J. Rua, A. Moreno, and V. Carreno. 1992. Persistence of hepatitis B virus DNA after reduction of viral replication in serum and liver. J. Med. Virol. 38:11-15.

11. Mason, A., B. Yoffe, C. Noonan, M. Mearns, C. Campbell, A. Kelley, and R. B. Perrillo. 1992. Hepatitis B virus DNA in peripheral-blood mononuclear cells in chronic hepatitis B after HBsAg clearance. Hepatology. 16:36-41.

12. Gilles, P. N., G. Fey, and F. V. Chisari. 1992. Tumor necrosis factor alfa negatively regulates hepatitis $\mathrm{B}$ virus genome expression in transgenic mice. $J$. Virol. 66:3955-3960.

13. Pasquinelli, C., M. Melegari, E. Villa, P. P. Scaglioni, M. Seidenari, N. Mongiardo, B. De Rienzo, and F. Manenti. 1990. Hepatitis B virus infection of peripheral blood mononuclear cells is common in acute and chronic hepatitis. $J$. Med. Virol. 31:135-140.

14. Chomczynski, P., and M. Sacchi. 1987. Single-step method of RNA isolation by acid guanidinium thiocyanate-phenol-chloroform extraction. Anal. Biochem. 1962:156-9.

15. Minshull, J., and T. Hunt. 1986. The use of single-stranded DNA and RNAse $\mathrm{H}$ to promote quantitative hybrid arrest of translation of mRNA:DNA hybrids in reticulocyte lysate cell-free translations. Nucleic Acids Res. 14:64336450.

16. Chemin, I., I. Baginski, C. Vermot-Desroches, O. Hantz, C. Jacquet, D. Rigal, and C. Trepo. 1992. Demonstration of woodchuck hepatitis virus infection of peripheral blood mononuclear cells by flow cytometry and polymerase chain reaction. J. Gen. Virol. 73:123-129.

17. Sambrook, J., E. F. Fritsch, and T. Maniatis. 1989. Molecular Cloning: A Laboratory Manual. Cold Spring Harbor Laboratory Press, Cold Spring Harbor, NY. 9.31.

18. Courouce-Pauty, A. M., A. Plancon, and J. P. Soulier. 1983. Distribution of $\mathrm{HBsAg}$ subtypes in the world. Vox Sang. 44:197-211.

19. Michalak, T. I., I. U. Pardoe, and F. V. Chisari. 1993. Heparin inhibits detection of HBV DNA and WHV DNA by the polymerase chain reaction. Molecular Biology of Hepatitis B Viruses 1993 Meeting, Georgetown University, Washington, DC. 98. (Abstr.)

20. Liang, T. J., H. E. Blum, and J. R. Wands. 1990. Characterization and biological properties of a hepatitis $B$ virus isolated from a patient without hepatitis B virus serologic markers. Hepatology. 12:204-212.

21. Loriot, M. A., P. Marcellin, E. Bismuth, M. Martinot-Peignoux, N. Boyer, C. Degott, S. Erlinger, and J. P. Benhamou. 1992. Demonstration of hepatitis B virus DNA by polymerase chain reaction in serum and liver after spontaneous or therapeutically induced $\mathrm{HBeAg}$ to anti-HBe or $\mathrm{HBsAg}$ to anti-HBs seroconversion in patients with chronic hepatitis B. Hepatology. 15:32-36.

22. Korenman, J., B. Baker, J. Waggoner, J. E. Everhart, A. M. Di Bisceglie and J. H. Hoofnagle. 1991. Long-term remission of chronic hepatitis B after $\alpha$-interferon therapy. Ann. Intern. Med. 114:629-634.

23. Shafritz, D. A., H. M. Lieberman, K. J. Isselbacher, and J. R. Wands. 1982. Monoclonal radioimmunoassays for hepatitis B surface antigen: demon- 
stration of hepatitis B virus DNA or related sequences in serum and viral epitopes in immune complexes. Proc. Natl. Acad. Sci. USA. 79:5675-5679.

24. Kaplan, P. M., E. C. Ford, and J. L. Gerin. 1976. Demonstration of subpopulations of Dane particles. J. Virol. 17:885-893.

25. Holodniy, M., S. Kim, D. Katzenstein, M. Konrad, E. Groves, and T. C. Merigan. 1991. Inhibition of human immunodeficiency virus gene amplification by heparin. J. Clin. Microbiol. 29:676-679.

26. Wang, J. T., T.-H. Wang, J.-C. Sheu, S.-M. Lin, J.-T. Lin, and D.-S. Chen 1992. Effect of anticoagulants and storage of blood samples on efficacy of the polymerase chain reaction assay for hepatitis C virus. J. Clin. Microbiol. 30:750753.

27. Wang, J.-T., T.-H. Wang, J.-C. She, L.-N. Shih, J.-T. Lin, and D.-S. Chen. 1991. Detection of hepatitis B virus DNA by polymerase chain reaction in plasma of volunteer blood donors negative for hepatitis B surface antigen. J. Infect. Dis. 163:397-399.

28. Baginski, I., P. Chemin, P. Bouffard, O. Hantz, and C. Trepo. 1992. Detection of polyadenylated RNA in hepatitis B virus-induced peripheral blood mononuclear cells by polymerase chain reaction. J. Infect. Dis. 163:996-1000.

29. Yoffe, B., C. A. Noonan, J. L. Melnick, and F. B. Hollinger. 1986. Hepatitis virus DNA in mononuclear cells and analysis of cell subsets for the presence of replicative intermediates of viral DNA. J. Infect. Dis. 153:471-477.

30. Korba, B. E., F. Wells, B. C. Tennant, G. H. Yoakum, R. H. Purcell, and J. L. Gerin. 1986. Hepadnavirus infection of peripheral blood lymphocytes in vitro: woodchuck and chimpanzee models of viral hepatitis. J. Virol. 58:1-8.

31. Noonan, C., B. Yoffe, P. Mansell, J. Melnick, and B. Hollinger. 1986 Exrachromosomal sequences of hepatitis B virus DNA in peripheral blood mononuclear cells of acquired immune deficiency syndrome patients. Proc. Natl. Acad. Sci. USA. 83:5698-5702.
32. Korba, B. E., F. Wells, B. C. Tennant, P. Cote, and J. L. Gerin. 1987 Lymphoid cells in the spleens of woodchucks hepatitis virus-infected woodchucks are a site of active viral replication. J. Virol. 61:1318-1324.

33. Hadchouel, M., C. Pasquinelli, J. G. Fournier, R. N. Hugon, J. Scotto, O. Bernard, and C. Brechot. 1988. Detection of mononuclear cells expressing hepatitis $\mathrm{B}$ virus in peripheral blood from $\mathrm{HBsAg}$ positive and negative patients by in situ hybridisation. J. Med. Virol. 24:27-32.

34. Lobbiani, A., F. Lalatta, F. Lugo, and G. Colucci. 1990. Hepatitis B virus transcripts and surface antigen in human peripheral blood lymphocytes. J. Med. Virol. 31:190-194.

35. Romet-Lemonne, J.-L., M. F. McLane, E. Elfassi, W. A. Haseltine, J. Azocar, and M. Essex. 1983. Hepatitis B virus infection in cultured human lymphoblastoid cells. Science (Wash. DC). 221:667-669.

36. Pontisso, P., M. C. Poon, P. Tiollais, and C. Brechot. 1984. Detection of hepatitis B virus DNA in mononuclear blood cells. Br. Med. J. 288:1563-1566.

37. Korba, B. E., P. J. Cote, and J. L. Gerin. 1988. Mitogen-induced replication of woodchuck hepatitis virus in cultured peripheral blood lymphocytes Science (Wash. DC). 241:1213-1216.

38. Korba, B. E., P. J. Cote, M. Shapiro, R. H. Purcell, and J. L. Gerin. 1989. In vitro production of infectious woodchuck hepatitis virus by lipopolysaccharide-stimulated peripheral blood lymphocytes. J. Infect. Dis. 160:572-576.

39. Galibert, F., E. Mandart, F. Fitoussi, P. Tiollais, and P. Charnay. 1979. Nucleotide sequence of the hepatitis B virus genome (subtype ayw) cloned in $E$. coli. Nature (Lond.). 281:646-650.

40. Sutcliffe, J. G. 1978. Complete nucleotide sequence of the Escherichia coli plasmid pBR322. Cold Spring Harbor Symp. Quant. Biol. 43:77-90. 